\title{
Potential Mechanisms Involved in Palmitoylethanolamide-Induced Vasodepressor Effects in Rats
}

\author{
Bruno A. Marichal-Cancino ${ }^{a}$ Abimael González-Hernández ${ }^{\text {b }}$ \\ Antoinette MaassenVanDenBrink ${ }^{c}$ Eduardo Ramírez-San Juan ${ }^{d}$ \\ Carlos M. Villalón ${ }^{\mathrm{e}}$ \\ a Departamento de Fisiología y Farmacología, Centro de Ciencias Básicas, Universidad Autónoma de Aguascalientes,

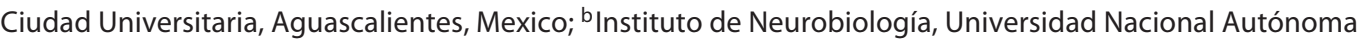 \\ de México, Campus UNAM-Juriquilla, Querétaro, Mexico; ' Division of Vascular Medicine and Pharmacology, \\ Department of Internal Medicine, Erasmus University Medical Center, Rotterdam, The Netherlands; \\ ${ }^{\mathrm{d} D e p a r t a m e n t o ~ d e ~ F i s i o l o g i ́ a, ~ E s c u e l a ~ N a c i o n a l ~ d e ~ C i e n c i a s ~ B i o l o ́ g i c a s, ~ I n s t i t u t o ~ P o l i t e ́ c n i c o ~ N a c i o n a l, ~ M e x i c o ~ C i t y, ~}$ \\ Mexico; ${ }^{e}$ Departamento de Farmacobiología, Cinvestav-Coapa, Mexico City, Mexico
}

\section{Keywords}

Cannabinoid $\mathrm{CB}_{1}$ receptor $\cdot \mathrm{GPR} 55$ receptor $\cdot$ Sympathetic vasopressor outflow

\begin{abstract}
Palmitoylethanolamide is an endogenous lipid that exerts complex vascular effects, enhances the effects of endocannabinoids and induces a direct hypotension, but the mechanisms involved have been poorly explored. Hence, this study investigated in Wistar pithed rats the role of $\mathrm{CB}_{1}, \mathrm{CB}_{2}$, TRPV1 and GPR55 receptors in the inhibition by palmitoylethanolamide of the vasopressor responses produced by sympathetic stimulation or exogenous noradrenaline. Frequencyand dose-dependent vasopressor responses were analysed before and during intravenous (i.v.) continuous infusions of palmitoylethanolamide in animals receiving i.v. bolus of the antagonists NIDA41020 $\left(\mathrm{CB}_{1}\right), \mathrm{AM} 630\left(\mathrm{CB}_{2}\right)$, capsazepine (TRPV1), and/or cannabidiol (GPR55). Palmitoylethanolamide $(0.1-3.1 \mu \mathrm{g} / \mathrm{kg} / \mathrm{min})$ dose-dependently inhibited the sympathetically induced and noradrenaline-induced vasopressor responses. Both inhibitions were: (i) partially blocked by $100 \mu \mathrm{g} / \mathrm{kg}$ NIDA41020, $100 \mu \mathrm{g} / \mathrm{kg}$ capsazepine,
\end{abstract}

or $31 \mu \mathrm{g} / \mathrm{kg}$ cannabidiol; (ii) unaffected by $310 \mu \mathrm{g} / \mathrm{kg}$ AM630; and (iii) abolished by the combination NIDA41020 + capsazepine + cannabidiol $(100,100$, and $31 \mu \mathrm{g} / \mathrm{kg}$, respectively). The resting blood pressure was decreased by palmitoylethanolamide (effect prevented by NIDA41020, capsazepine or cannabidiol, but not by AM630). These results suggest that: (i) palmitoylethanolamide inhibits the vasopressor responses to sympathetic stimulation and exogenous noradrenaline and that it induces hypotension; and (ii) all these effects are mediated by prejunctional and vascular $\mathrm{CB}_{1}, \mathrm{TRPV} 1$ and probably GPR55, but not by $\mathrm{CB}_{2}$, receptors.

(C) 2020 S. Karger AG, Basel

\section{Introduction}

Endogenous cannabinoids and related mediators (i.e., endocannabinoids and endocannabinoid-like compounds) play a role in the modulation of a wide variety of physiological functions with potential therapeutic use [17]. In cardiovascular homeostasis, they exert actions on systemic blood pressure and local blood flow by mechanisms partially elucidated, including: (i) autonomic and

\section{KARGER}

(c) 2020 S. Karger AG, Basel 
sensory neural modulation [8,9]; (ii) stimulation of endothelial nitric oxide [10]; and (iii) control of smooth muscle cell activity [11]. Modulation of vascular tone by endocannabinoids involves activation of vascular and prejunctional G-protein-coupled receptors $\left(\mathrm{CB}_{1}, \mathrm{CB}_{2}\right.$ and GPR55), capsaicin receptors (TRPV1) and nuclear receptors (PPAR $\alpha$ and PPAR $\gamma$ ) $[8,9,12]$. The modulation of vascular tone by cannabinoids is of such importance that they induce prolonged hypotension in the nanomolar range doses [13].

Palmitoylethanolamide is an $\mathrm{N}$-acylethanolamine (a fatty acid amide structurally related to the endocannabinoid anandamide) that stands out for its capability to $\mathrm{mimic} /$ potentiate some of the vascular effects induced by anandamide, including vasodilatation [14]. Its effects in the cardiovascular system have been mainly related to an "entourage" action. This "entourage" action may involve, among others, an increase in: (i) the levels of other $\mathrm{N}$ acylethanolamines (and its actions) because palmitoylethanolamide has more affinity for the main enzyme involved in endocannabinoids degradation (i.e., fatty acid amide hydrolase); and (ii) the affinity of other endocannabinoids for their targets [15-17].

Interestingly, palmitoylethanolamide: (i) is present in human plasma at $14 \mathrm{pmol} / \mathrm{mL}$ [18], and values in the picomolar range are also observed in rodents [19]; (ii) is detected in several tissues where endocannabinoids exert regulatory effects [15-17]; and (iii) displays high affinity for (Table 1) and can activate [18] the cannabinoid/lysophospholipid receptor GPR55. As GPR55 activation results in vasodilatation $[8,10]$, palmitoylethanolamide might be involved in the vascular physiological actions of activation of GPR55. Nevertheless, the pharmacological nature of the systemic vascular mechanisms by which palmitoylethanolamide induces hypotension and vasorelaxation remains unknown. On this basis, the present study in pithed rats was designed in an attempt to analyse the effects produced by intravenous (i.v.) continuous infusions of palmitoylethanolamide on: (i) the vasopressor responses induced by selective preganglionic sympathetic stimulation or exogenous noradrenaline, and (ii) resting diastolic blood pressure (an indicator of total peripheral vascular resistance; TPVR). Furthermore, the potential role of $\mathrm{CB}_{1}, \mathrm{CB}_{2}$, TRPV1, and GPR55 receptors in the above palmitoylethanolamide effects on diastolic blood pressure was investigated by using the corresponding selective antagonists for these receptors (Table 1). Within this context, it is noteworthy that systolic blood pressure is generated during heart contraction, and thus it better reflects the
Table 1. Binding affinity constants $\left(\mathrm{p} K_{\mathrm{i}}\right)$ of several ligands for $\mathrm{CB}_{1}$, $\mathrm{CB}_{2}$, TRPV1 and GPR55 receptors, except for ${ }^{\alpha}, \beta$ and $\gamma$, which stand for $\mathrm{pEC}_{50}, \mathrm{PK}_{\mathrm{B}}$ and $\mathrm{pIC}_{50}$, respectively, determined in transfected cells

\begin{tabular}{lllll}
\hline Compound & $\mathrm{CB}_{1}$ & $\mathrm{CB}_{2}$ & TRPV1 & GPR55 \\
\hline $\begin{array}{l}\text { Agonist } \\
\text { Palmitoylethanolamide }\end{array}$ & $<4.5^{\alpha, \mathrm{a}}$ & $<5.7^{\alpha, \mathrm{a}}$ & $\mathrm{ND}$ & $8.4^{\alpha, \mathrm{a}}$ \\
\hline $\begin{array}{l}\text { Antagonists } \\
\text { NIDA42020 }\end{array}$ & $\sim 8.4^{\mathrm{b}}$ & $6.0^{\beta, \mathrm{c}}$ & $\mathrm{ND}$ & $\mathrm{ND}$ \\
AM630 & $\sim 5.2^{\mathrm{d}}$ & $\sim 7.5^{\mathrm{d}}$ & $\mathrm{ND}$ & $\mathrm{ND}$ \\
Capsazepine & $\mathrm{ND}$ & $\mathrm{ND}$ & $\sim 5.8^{\mathrm{e}}(\mathrm{r})$ & $\mathrm{ND}$ \\
Cannabidiol & $\sim 5.3^{\mathrm{f}}$ & $\sim 5.4^{\mathrm{f}}$ & $\mathrm{ND}$ & $6.3^{\gamma, \mathrm{a}}$ \\
\hline
\end{tabular}

$(\mathrm{r})$, interaction of anandamide with vanilloid receptors in $\mathrm{CHO}$ cells transfected with rVR1 (TRPV1) receptors; ND, not determined; , approximately.

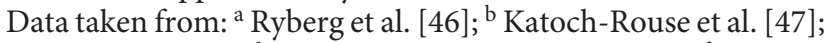
${ }^{\mathrm{c}}$ Donohue et al. [48]; ${ }^{\mathrm{d}}$ Ross et al. [49]; ${ }^{\mathrm{e}}$ Ross et al. [50]; ${ }^{\mathrm{f}}$ Thomas et al. [51].

phenomena in conductance blood vessels [19]. In contrast, diastolic blood pressure (which is generated during left ventricular relaxation) is directly proportional to TPVR [19]; in other words, an increment in TPVR results in a higher diastolic blood pressure [20].

On the other hand, it is important to highlight that in pithed rats the central nervous system has been destroyed. Consequently, the autonomic nervous control of visceral actions is absent, with only the local and hormonal systems remaining (e.g., the renin-angiotensin-aldosterone system; RAAS).

\section{Methods}

Animals

Healthy male normotensive Wistar rats (250-300 g) were maintained under a 12/12-h light-dark cycle (with light beginning at 07:00 h) and kept in a special room at $22 \pm 2{ }^{\circ} \mathrm{C}$ and $50 \%$ humidity, with food and water ad libitum in their home cages.

\section{General Methods}

Experiments were carried out in 120 rats. After anaesthesia with diethyl ether and cannulation of the trachea, the rats were pithed by inserting a stainless-steel rod as previously reported [21, 22]. Immediately afterwards, the animals were artificially ventilated with room air using a model 7,025 Ugo Basile pump (56 strokes/min; stroke volume: $20 \mathrm{~mL} / \mathrm{kg}$ ), as established by Kleinman and Radford [23]. After bilateral cervical vagotomy, catheters were placed in the left and right femoral and jugular veins for: (i) the infusion of the agonists by a WPI model sp100i pump 
(World Precision Instruments Inc., Sarasota, FL, USA); and (ii) bolus injections of the antagonists or vehicles. The left carotid artery was connected to a Grass pressure transducer (P23 XL) for the recording of blood pressure. Heart rate was measured with a tachograph (7P4, Grass Instrument Co., Quincy, MA, USA) triggered from the blood pressure signal. Both blood pressure and heart rate were recorded simultaneously by a model 7 Grass polygraph (Grass Instrument Co., Quincy, MA, USA).

Then, the 120 rats were divided into two main sets, so that the effects produced by i.v. continuous infusions of dimethyl sulfoxide 0.5\% (DMSO; vehicle) or palmitoylethanolamide could be investigated on the vasopressor responses induced by either: (i) selective preganglionic $\left(\mathrm{T}_{7}-\mathrm{T}_{9}\right)$ stimulation of the vasopressor sympathetic outflow (set $1 ; n=80$ ), or (ii) i.v. bolus injections of exogenous noradrenaline (set $2 ; n=40$ ).

The vasopressor stimulus-response curves ( $\mathrm{S}-\mathrm{R}$ curves) and dose-response curves (D-R curves) elicited by sympathetic stimulation and exogenous noradrenaline, respectively, were completed in about $30 \mathrm{~min}$. Moreover, the vasopressor sympathetic stimuli and the noradrenaline injections were given using a sequential schedule, in $0.5 \log$ unit increments at 3 - to 5 -min intervals. The body temperature of each pithed rat was maintained at $37^{\circ} \mathrm{C}$ by a lamp and monitored with a rectal thermometer.

\section{Experimental Protocols}

After the animals had been in a stable haemodynamic condition for at least $20 \mathrm{~min}$, baseline values of diastolic blood pressure (an indicator of systemic vascular tone) and heart rate were determined. Subsequently, the following experimental protocols were applied.

Electrical Stimulation of the Vasopressor Sympathetic

Outflow

In the first set of rats $(n=80)$, the pithing rod was replaced by an electrode enamelled except for a $1-\mathrm{cm}$ length $9 \mathrm{~cm}$ from the tip, so that the uncovered segment was situated at $\mathrm{T}_{7}-\mathrm{T}_{9}$ in the spinal cord to allow selective preganglionic stimulation of the thoracic sympathetic nerves supplying the systemic vasculature (i.e., the vasopressor sympathetic outflow); an indifferent electrode was placed dorsally $[22,24,25]$. Prior to electrical stimulation, all animals were pretreated with: (i) gallamine $(25 \mathrm{mg} / \mathrm{kg}$, i.v. $)$ to avoid electrically induced muscular twitching; and (ii) after $10 \mathrm{~min}$, desipramine $(50 \mu \mathrm{g} / \mathrm{kg}$, i.v.) before each S-R curve to induce higher vasopressor responses at low stimulation frequencies, as previously established $[25,22]$. Under these conditions, the vasopressor responses to lower stimulation frequencies are greater than those elicited without desipramine [22, 25-27]. Ten minutes later, baseline values of diastolic blood pressure and heart rate were determined again.

The preganglionic vasopressor sympathetic outflow was then stimulated to elicit vasopressor responses by applying $10-\mathrm{s}$ trains $(2 \mathrm{~ms}$ monophasic rectangular pulses, $50 \mathrm{~V}$ ) at increasing frequencies $(0.03,0.1,0.3,1$ and $3 \mathrm{~Hz})$ using a sequential schedule, as previously described [22, 25-27]. When diastolic blood pressure had returned to baseline levels, the next frequency was applied. This procedure was performed systematically until the S-R curve had been completed (about $30 \mathrm{~min}$ ). At this point, this set of animals was divided into three treatment groups $(n=15,30$ and 35).

Vasodepressor Actions of

Palmitoylethanolamide
The first group ( $n=15)$ was subdivided into three subgroups ( $n=5$ each) that received an i.v. continuous infusion of: (i) DMSO $0.5 \%$ (vehicle of palmitoylethanolamide, two times; $0.02 \mathrm{~mL} / \mathrm{min}$ ); (ii) palmitoylethanolamide ( 0.1 and $0.31 \mu \mathrm{g} / \mathrm{kg} / \mathrm{min}$ ), and (iii) palmitoylethanolamide ( 1 and $3.1 \mu \mathrm{g} / \mathrm{kg} / \mathrm{min}$ ). Ten minutes later, an $\mathrm{S}$-R curve was elicited again during the above infusions to analyse their effects on the sympathetically induced vasopressor responses. The intervals between the different infusions ranged between 10 and $15 \mathrm{~min}$, as in each case we waited until the diastolic blood pressure returned to baseline values.

The second group $(n=30)$ was subdivided into six subgroups ( $n=5$ each) that received an i.v. bolus injection of: (i) DMSO $2 \%$ (vehicle of antagonists); (ii) NIDA41020 (100 $\mu \mathrm{g} / \mathrm{kg}$ ); (iii) AM630 $(310 \mu \mathrm{g} / \mathrm{kg})$; (iv) capsazepine $(100 \mu \mathrm{g} / \mathrm{kg})$; (v) cannabidiol $(31 \mu \mathrm{g} /$ $\mathrm{kg}$ ); and (vi) the combination of $100 \mu \mathrm{g} / \mathrm{kg}$ NIDA41020 + $100 \mu \mathrm{g} /$ $\mathrm{kg}$ capsazepine $+31 \mu \mathrm{g} / \mathrm{kg}$ cannabidiol. Twenty minutes later, an $\mathrm{S}-\mathrm{R}$ curve was elicited again, as described above, to analyse their effects per se on the sympathetically induced vasopressor responses.

The third group $(n=35)$, subdivided into seven subgroups ( $n=5$ each), received an i.v. bolus injection of: (i) $1 \mathrm{~mL} / \mathrm{kg}$ DMSO 2\%; (ii) $100 \mu \mathrm{g} / \mathrm{kg}$ NIDA41020; (iii) $310 \mu \mathrm{g} / \mathrm{kg}$ AM630; (iv) $31 \mu \mathrm{g} /$ $\mathrm{kg}$ capsazepine; (v) $100 \mu \mathrm{g} / \mathrm{kg}$ capsazepine; (vi) $31 \mu \mathrm{g} / \mathrm{kg}$ cannabidiol; and (vii) the combination of $100 \mu \mathrm{g} / \mathrm{kg}$ NIDA41020 + $100 \mu \mathrm{g} /$ $\mathrm{kg}$ capsazepine $+31 \mu \mathrm{g} / \mathrm{kg}$ cannabidiol.

Ten minutes later, all subgroups received an i.v. continuous infusion of palmitoylethanolamide $(3.1 \mu \mathrm{g} / \mathrm{kg} / \mathrm{min})$. After $10 \mathrm{~min}$, an S-R curve was constructed again during the infusion of palmitoylethanolamide as described above, to analyse the effects of the aforementioned compounds on palmitoylethanolamide-induced inhibition of the electrically induced vasopressor responses.

\section{Administration of Exogenous Noradrenaline}

The second set of rats $(n=40)$ was prepared as described above, but the pithing rod was left in situ and not replaced by the stimulating electrode throughout the experiment (as electrical stimulation was not used). After determining baseline values of diastolic blood pressure and heart rate, vasopressor responses were elicited by administering i.v. bolus injections of exogenous noradrenaline at increasing doses $(0.03,0.1,0.3,1$ and $3 \mu \mathrm{g} / \mathrm{kg})$ as previously described [22, 25-27]. When diastolic blood pressure had returned to baseline levels, the next dose was applied. This procedure was performed until the D-R curve had been completed (about $30 \mathrm{~min}$ ). Subsequently, the animals were divided into two groups ( $n=10$ and 30, respectively).

The first group $(n=10)$ was subdivided into two subgroups ( $n=5$ each) that, respectively, received i.v. continuous infusions of: (i) DMSO $0.5 \%$ (two times; $0.02 \mathrm{~mL} / \mathrm{min}$ ), and (ii) palmitoylethanolamide ( 1 and $3.1 \mu \mathrm{g} / \mathrm{kg} / \mathrm{min}$ ). Ten minutes after starting these infusions, a D-R curve for noradrenaline was elicited again.

The second group $(n=30)$ was subdivided into six subgroups ( $n=5$ each) that received an i.v. bolus injection of: (i) $1 \mathrm{~mL} /$ kg DMSO 2\%; (ii) $100 \mu \mathrm{g} / \mathrm{kg}$ NIDA41020; (iii) 310 \%g/kg AM630; (iv) $100 \mu \mathrm{g} / \mathrm{kg}$ capsazepine; (v) $31 \mu \mathrm{g} / \mathrm{kg}$ cannabidiol; and (vi) the combination of $100 \mu \mathrm{g} / \mathrm{kg}$ NIDA41020 + $100 \mu \mathrm{g} / \mathrm{kg}$ capsazepine + $31 \mu \mathrm{g} / \mathrm{kg}$ cannabidiol.

Ten minutes later, all subgroups received an i.v. continuous infusion of palmitoylethanolamide $(3.1 \mu \mathrm{g} / \mathrm{kg} / \mathrm{min})$. After $10 \mathrm{~min}$, a D-R curve for noradrenaline was elicited again to analyse the effects of the aforementioned compounds on palmitoylethanolamide-induced inhibition of the vasopressor responses induced by noradrenaline. 
Table 2. Effects of the different i.v. continuous infusions of compounds ( $n=5 \mathrm{each}$ ) on the basal values of diastolic blood pressure determined $10 \mathrm{~min}$ after a stable condition with no treatment (basal) or $10 \mathrm{~min}$ after each corresponding infusion had commenced

\begin{tabular}{|c|c|c|c|}
\hline \multirow[t]{2}{*}{ Treatment } & \multicolumn{3}{|c|}{ Diastolic blood pressure, $\mathrm{mm} \mathrm{Hg}$} \\
\hline & basal & $\begin{array}{l}\text { after 1st } \\
\text { dose } \\
\text { treatment }\end{array}$ & $\begin{array}{l}\text { after } 2 \mathrm{nd} \\
\text { dose } \\
\text { treatment }\end{array}$ \\
\hline $\begin{array}{l}\text { DMSO } 0.5 \%(0.02 \mathrm{~mL} / \mathrm{min} \text {; } \\
\text { given twice) }\end{array}$ & $49 \pm 8$ & $53 \pm 5$ & $51 \pm 2$ \\
\hline $\begin{array}{l}\text { Palmitoylethanolamide } \\
\qquad(0.1 \text { and } 0.31 \mu \mathrm{g} / \mathrm{kg} / \mathrm{min})\end{array}$ & $59 \pm 6$ & $54 \pm 5$ & $51 \pm 6$ \\
\hline $\begin{array}{l}\text { Palmitoylethanolamide } \\
\text { (1 and } 3.1 \mu \mathrm{g} / \mathrm{kg} / \mathrm{min})\end{array}$ & $54 \pm 7$ & $48 \pm 6^{\mathrm{a}}$ & $42 \pm 5^{\mathrm{a}}$ \\
\hline
\end{tabular}

All values are expressed as the mean \pm SEM. ${ }^{a} p<0.05$ versus the corresponding basal value. DMSO, dimethyl sulfoxide.

Table 3. Effect of the different i.v. bolus injections of compounds (i.e., before starting the infusion of palmitoylethanolamide) on the hypotension induced by $3.1 \mu \mathrm{g} / \mathrm{kg} / \mathrm{min}$ palmitoylethanolamide

\begin{tabular}{|c|c|c|}
\hline \multirow[t]{2}{*}{ Pretreatment } & \multicolumn{2}{|c|}{ Diastolic blood pressure, $\mathrm{mm} \mathrm{Hg}$} \\
\hline & basal & palmitoylethanolamide \\
\hline DMSO $0.5 \%, 1 \mathrm{~mL} / \mathrm{kg}$ & $60 \pm 5$ & $41 \pm 4^{\mathrm{a}}$ \\
\hline DMSO $2 \%, 1 \mathrm{~mL} / \mathrm{kg}$ & $60 \pm 3$ & $43 \pm 2^{\mathrm{a}}$ \\
\hline NIDA41020, $100 \mu \mathrm{g} / \mathrm{kg}$ & $50 \pm 7$ & $46 \pm 9$ \\
\hline $\mathrm{AM} 630,310 \mu \mathrm{g} / \mathrm{kg}$ & $50 \pm 4$ & $40 \pm 4^{\mathrm{a}}$ \\
\hline Capsazepine, $31 \mu \mathrm{g} / \mathrm{kg}$ & $57 \pm 9$ & $49 \pm 9$ \\
\hline Capsazepine, $100 \mu \mathrm{g} / \mathrm{kg}$ & $51 \pm 6$ & $46 \pm 7$ \\
\hline Cannabidiol, $31 \mu \mathrm{g} / \mathrm{kg}$ & $52 \pm 11$ & $44 \pm 9$ \\
\hline Combination $^{\mathrm{b}}$ & $64 \pm 9$ & $63 \pm 3$ \\
\hline
\end{tabular}

All values are expressed as the mean \pm SEM. The basal values shown in this table correspond to those obtained 10 min after administering the above compounds. ${ }^{a} p<0.05$ versus the corresponding basal value. ${ }^{\mathrm{b}}$ Combination of $100 \mu \mathrm{g} / \mathrm{kg}$ NIDA41020 + $100 \mu \mathrm{g} / \mathrm{kg}$ capsazepine $+31 \mu \mathrm{g} / \mathrm{kg}$ cannabidiol.

\section{Drugs}

Apart from the anaesthetic (diethyl ether), the compounds used in this study (obtained from the sources indicated) were: gallamine triethiodide, desipramine hydrochloride, (-)-noradrenaline bitartrate, palmitoylethanolamide, capsazepine and NIDA41020 (1-[2,4-dichlorophenyl]-5-[4-methoxyphenyl]-4methyl-N-[1-piperidinyl]-1H-pyrazole-3-carboxamide; Sigma Chemical Co., St Louis, MO, USA); AM630 (6-iodo-2-methyl1-[2-(4-morpholinyl)ethyl]-1H-indol-3-yl(4-methoxyphenyl) methanone; Santa Cruz Biotechnology Inc., Santa Cruz, CA, USA), and cannabidiol (TOCRIS, Avonmouth, UK).
The compounds were dissolved as follows: (i) palmitoylethanolamide in DMSO 0.5\%; (ii) gallamine, desipramine, and noradrenaline in physiological saline, and (iii) NIDA41020, AM630, capsazepine and cannabidiol in DMSO 2\%. The resulting solutions were gauged with physiological saline. In the case of noradrenaline, ascorbic acid 1\% was used to prevent oxidation. These vehicles had no effect on baseline diastolic blood pressure or heart rate (not shown). Fresh solutions were prepared for each experiment. The doses mentioned in the text refer to the free base of substances, except in the case of gallamine and desipramine, where they refer to their corresponding salts.

\section{Data Presentation and Statistical Analysis}

All data in the text and figures are presented as means \pm SEM. It must be emphasised that the data and statistical analysis used in the present study comply with recent recommendations on experimental design and analysis in pharmacology, including that data subjected to statistical analysis should have a minimum of $n=5$ independent samples/individuals per group [28]. The peak changes in diastolic blood pressure by electrical stimulation or exogenous noradrenaline in saline- and agonist-infused animals were determined. The difference between the changes in diastolic blood pressure within one subgroup of animals was evaluated by the Student-Newman-Keuls post hoc test, once a two-way repeated measures analysis of variance (randomised block design) had revealed that the samples represented different populations [29]. Statistical significance was accepted at $p<$ 0.05 .

\section{Results}

\section{Systemic Haemodynamic Variables}

The baseline values of diastolic blood pressure and heart rate in the 120 rats were $54 \pm 7 \mathrm{~mm} \mathrm{Hg}$ and $296 \pm$ 13 beats/min, respectively. The i.v. administration of desipramine $(50 \mu \mathrm{g} / \mathrm{kg})$ produced a transient increase of both variables (not shown), but baseline values recovered after $5 \mathrm{~min}(p>0.05)$, as previously reported [22, 25-27]. The latter baseline values in desipramine-pretreated rats were not significantly modified during the continuous infusions of: (1) DMSO 0.5\% (control, two times, $0.02 \mathrm{~mL} / \mathrm{min}$; Table 2), and (ii) palmitoylethanolamide $(0.1-0.3 \mu \mathrm{g} / \mathrm{kg} / \mathrm{min}$; Table 2$)$. In contrast, the baseline values of diastolic blood pressure were significantly decreased by the continuous infusions of palmitoylethanolamide (1-3.1 $\mu \mathrm{g} / \mathrm{kg} / \mathrm{min}$; Table 2$)$. Furthermore, the diastolic blood pressure values (in the absence of agonists) were not modified ( $p>0.05)$ after i.v. bolus injections of: (i) 31 and $100 \mu \mathrm{g} / \mathrm{kg}$ NIDA41020; (ii) 310 $\mu \mathrm{g} / \mathrm{kg}$ AM630; (iii) 31-100 $\mu \mathrm{g} / \mathrm{kg}$ capsazepine; (iv) 31 $\mu \mathrm{g} / \mathrm{kg}$ cannabidiol; or (v) the combination of $100 \mu \mathrm{g} / \mathrm{kg}$ NIDA $41020+100 \mu \mathrm{g} / \mathrm{kg}$ capsazepine $+31 \mu \mathrm{g} / \mathrm{kg}$ cannabidiol (data not shown). 


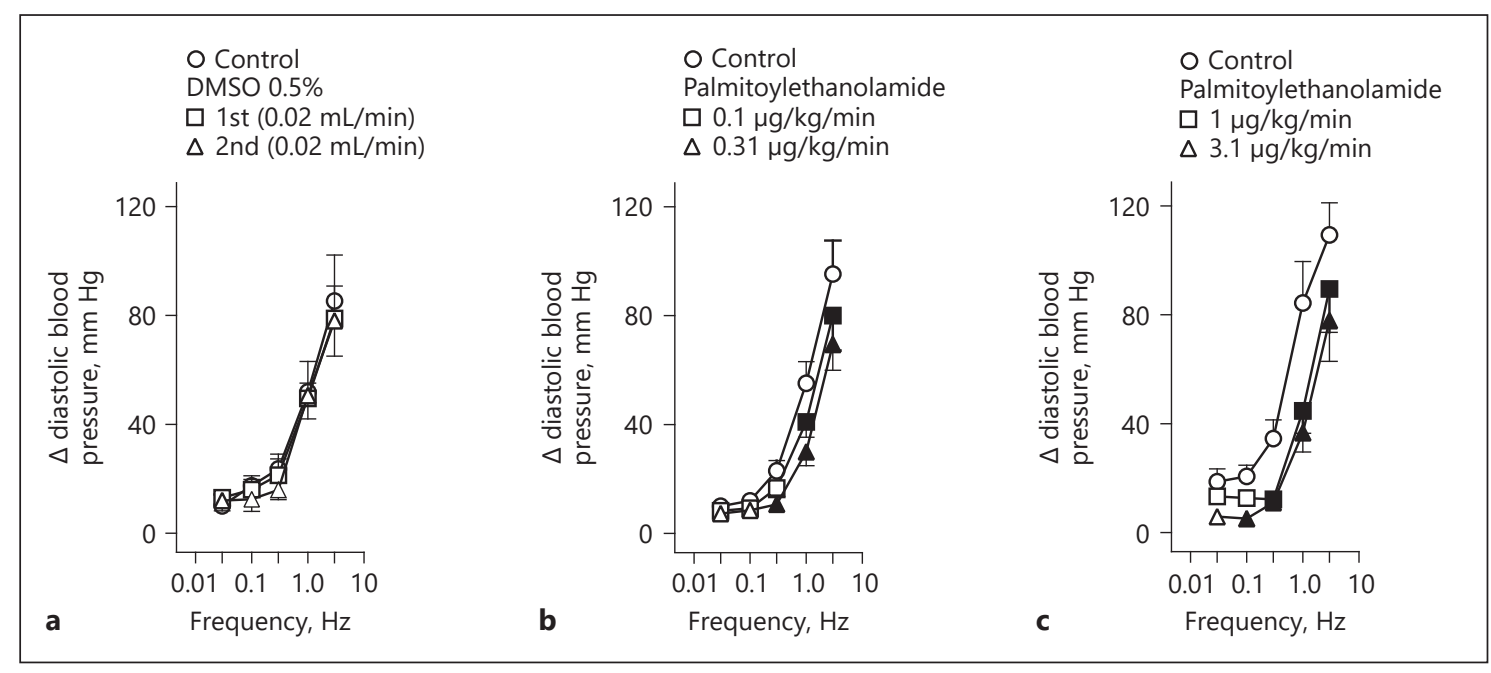

Fig. 1. Effect of an i.v. infusion ( $n=5$ for each figure) of: DMSO $0.5 \%(0.02 \mathrm{~mL} / \mathrm{min}$; twice; a) and palmitoylethanolamide $(0.1-3.1 \mu \mathrm{g} / \mathrm{kg} / \mathrm{min} ; \mathbf{b}, \mathbf{c})$ in the presence of desipramine (50 $\mu \mathrm{g} / \mathrm{kg}$, i.v.) on the vasopressor responses induced by electrical stimulation of the preganglionic $\left(\mathrm{T}_{7}-\mathrm{T}_{9}\right)$ sympathetic outflow in pithed rats. Empty symbols depict either control responses $(O)$ or non-significant $(p>0.05)$ responses $(\triangle, \square)$ versus the control. Solid symbols $(\boldsymbol{\Delta}, \boldsymbol{\square})$ represent significantly different responses $(p<0.05)$ versus the control.

Effect of the Antagonists on the Hypotensive Responses Produced by Palmitoylethanolamide

As shown in Table 3, the hypotensive responses induced by $3.1 \mu \mathrm{g} / \mathrm{kg} / \mathrm{min}$ palmitoylethanolamide: (i) remained unaltered after DMSO (0.5 and 2\%) or $310 \mu \mathrm{g} / \mathrm{kg}$ AM630, and (ii) were abolished by $100 \mu \mathrm{g} / \mathrm{kg}$ of NIDA41020, 31 or 100 $\mu \mathrm{g} / \mathrm{kg}$ of capsazepine, $31 \mu \mathrm{g} / \mathrm{kg}$ of cannabidiol or the combination $100 \mu \mathrm{g} / \mathrm{kg}$ of NIDA41020 $+100 \mu \mathrm{g} / \mathrm{kg}$ of capsazepine $+31 \mu \mathrm{g} / \mathrm{kg}$ of cannabidiol.

Initial Effects Produced by Electrical Sympathetic Stimulation or Exogenous Noradrenaline on Diastolic Blood Pressure and Heart Rate

The increases in diastolic blood pressure induced by electrical stimulation of the sympathetic vasopressor outflow $(0.03-3 \mathrm{~Hz})$ or by exogenous noradrenaline $(0.03-3$ $\mu \mathrm{g} / \mathrm{kg}$ ) were immediate, frequency-dependent (sympathetic stimulation), or dose-dependent (exogenous noradrenaline; see control responses in Fig. 1-5). As previously described [29, 30], i.v. bolus injections of noradrenaline also produced dose-dependent and transient increases in heart rate (not shown). The vasopressor responses to either electrical stimulation or noradrenaline were significant when compared with their corresponding baseline values (not shown). The electrically induced vasopressor responses are induced by selective sympathetic stimulation, as only negligible changes in heart rate were observed, as previously reported by our group $[5,29$, 31].

\section{Effect of i.v. Continuous Infusions of Vehicle or}

Palmitoylethanolamide on the Vasopressor Responses

Induced by Either Sympathetic Stimulation or

Exogenous Noradrenaline

Figure 1 shows the vasopressor responses induced by electrical stimulation before (control) and during the i.v. continuous infusion of DMSO $0.5 \%(0.02 \mathrm{~mL} / \mathrm{min} ; 2$ times) and palmitoylethanolamide $(0.1,0.3,1$, and $3.1 \mu \mathrm{g} /$ $\mathrm{kg} / \mathrm{min}$ ). In animals infused with DMSO $0.5 \%$, the electrically induced vasopressor responses remained essentially unchanged $(p>0.05)$ when repeating two subsequent S-R curves (Fig. 1a). In contrast, the infusions of palmitoylethanolamide $(0.1-3.1 \mu \mathrm{g} / \mathrm{kg} / \mathrm{min})$ produced a significant inhibition of the electrically induced vasopressor responses (Fig. 1b, c).

Moreover, Figure 2 shows the vasopressor responses induced by i.v. injections of noradrenaline before (control) and during i.v. continuous infusions of DMSO or palmitoylethanolamide. In animals infused with DMSO $0.5 \%(0.02 \mathrm{~mL} / \mathrm{min})$, the vasopressor responses to noradrenaline remained unchanged when repeating two subsequent D-R curves (Fig. 2a). In contrast, the infusions of 1 and $3.1 \mu \mathrm{g} / \mathrm{kg} / \mathrm{min}$ palmitoylethanolamide produced a dose-dependent inhibition of the vasopressor re- 
Fig. 2. Effect of an i.v. infusion $(n=5$ for each figure $)$ of: DMSO $0.5 \%(0.02 \mathrm{~mL} / \mathrm{min}$, twice; a) and palmitoylethanolamide (1 and $3.1 \mu \mathrm{g} / \mathrm{kg} / \mathrm{min}$; b) on the vasopressor responses induced by exogenous noradrenaline in pithed rats. Empty symbols depict either control responses $(O)$ or nonsignificant $(p>0.05)$ responses $(\triangle, \square)$ versus the control. Solid symbols $(\boldsymbol{\Lambda}, \boldsymbol{\square})$ represent significantly different responses $(p<$ $0.05)$ versus the control. * represents a significantly different response $(p<0.05)$ between palmitoylethanolamide $1 \mu \mathrm{g} / \mathrm{kg} / \mathrm{min}$ versus $3.1 \mu \mathrm{g} / \mathrm{kg} / \mathrm{min}$.

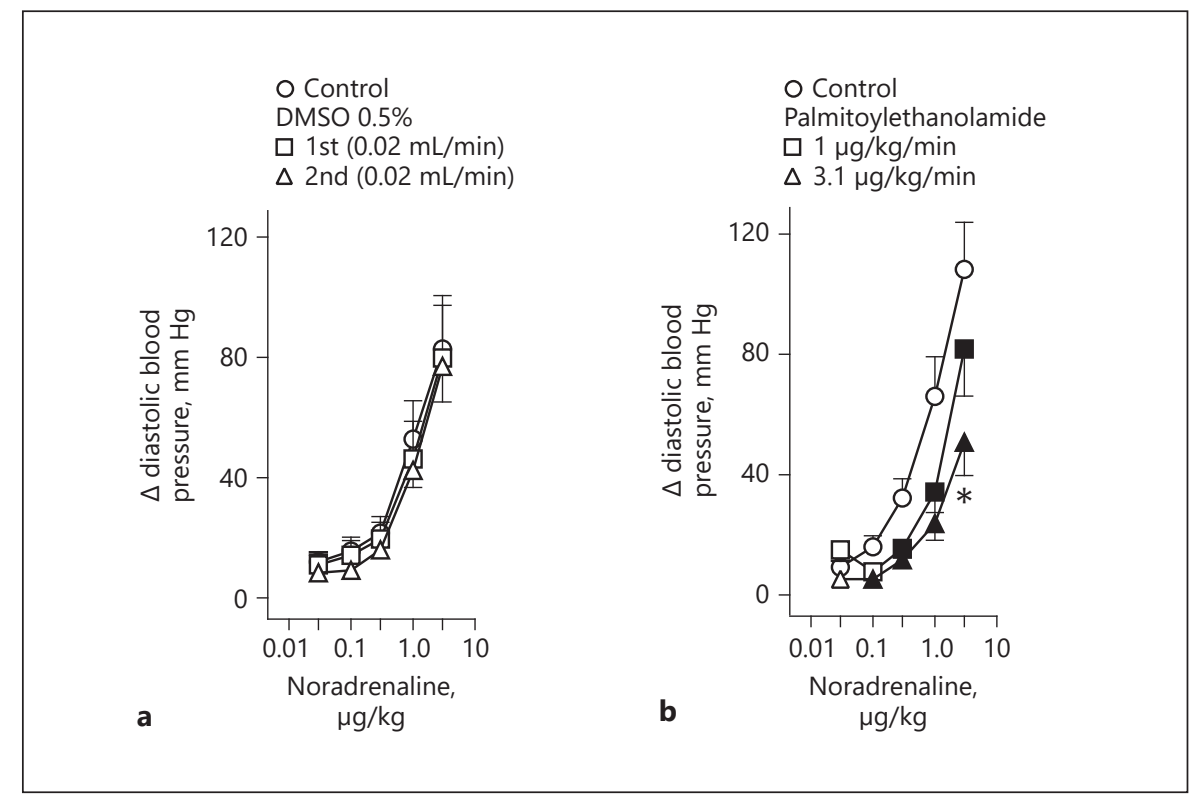

sponses. Indeed, $3.1 \mu \mathrm{g} / \mathrm{kg} / \mathrm{min}$ palmitoylethanolamide produced the highest inhibition of the vasopressor responses induced by either electrical stimulation (Fig. 1c) or i.v. noradrenaline (Fig. 2b). For this reason, $3.1 \mu \mathrm{g} / \mathrm{kg} /$ min of palmitoylethanolamide was chosen for further pharmacological analysis (see below).

\section{Effect per se of Vehicles or Antagonists on the}

Vasopressor Responses by Electrical Stimulation

Figure 3 shows that the electrically induced vasopressor responses remained unchanged (as compared with the control S-R curves; $p>0.05$ ) after an i.v. bolus injection of: (i) $1 \mathrm{~mL} / \mathrm{kg}$ DMSO 2\% (Fig. 3a); (ii) $100 \mu \mathrm{g} / \mathrm{kg}$ NIDA41020 (Fig. 3b); (iii) $310 \mu \mathrm{g} / \mathrm{kg}$ AM630 (Fig. 3c); (iv) $31 \mu \mathrm{g} / \mathrm{kg}$ cannabidiol (Fig. 3d); (v) $100 \mu \mathrm{g} / \mathrm{kg}$ capsazepine (Fig. 3e); and (vi) the combination $100 \mu \mathrm{g} / \mathrm{kg}$ NIDA41020 + $100 \mu \mathrm{g} / \mathrm{kg}$ capsazepine $+31 \mu \mathrm{g} / \mathrm{kg}$ cannabidiol (Fig. 3f).

\section{Effect of Vehicles or Antagonists on \\ Palmitoylethanolamide-Induced Inhibition of the \\ Vasopressor Responses to Sympathetic Electrical \\ Stimulation}

Figure 4 shows that the sympathoinhibition produced by $3.1 \mu \mathrm{g} / \mathrm{kg} / \mathrm{min}$ palmitoylethanolamide was: (i) unaltered after $1 \mathrm{~mL} / \mathrm{kg}$ of DMSO 0.5\% (Fig. 4a) or $310 \mu \mathrm{g} / \mathrm{kg}$ AM630 (Fig. 4c); (ii) partially blocked by $100 \mu \mathrm{g} / \mathrm{kg}$ of NIDA42020 (Fig. 4b), 31 and $100 \mu \mathrm{g} / \mathrm{kg}$ of capsazepine (Fig. 4d, e) or $31 \mu \mathrm{g} / \mathrm{kg}$ of cannabidiol (Fig. 4f); and (iii) abolished by the combination $100 \mu \mathrm{g} / \mathrm{kg}$ NIDA42020 + $100 \mu \mathrm{g} / \mathrm{kg}$ capsazepine $+31 \mu \mathrm{g} / \mathrm{kg}$ cannabidiol (Fig. $4 \mathrm{~g}$ ).

\section{Effect of Vehicles or Antagonists on}

Palmitoylethanolamide-Induced Inhibition of the

Vasopressor Responses to Exogenous Noradrenaline

As illustrated in Figure 5, the inhibition of the vasopressor responses to noradrenaline by $3.1 \mu \mathrm{g} / \mathrm{kg} / \mathrm{min}$ palmitoylethanolamide was: (i) unaltered after $1 \mathrm{~mL} /$ kg DMSO 0.5\% (Fig. 5a) or $310 \mu \mathrm{g} / \mathrm{kg}$ AM630 (Fig. 5c); (ii) partially blocked by $100 \mu \mathrm{g} / \mathrm{kg}$ NIDA42020 (Fig. 5b), $100 \mu \mathrm{g} / \mathrm{kg}$ capsazepine (Fig. $5 \mathrm{~d}$ ), or $31 \mu \mathrm{g} / \mathrm{kg}$ cannabidiol (Fig. 5e); and (iii) abolished by the combination $100 \mu \mathrm{g} /$ $\mathrm{kg}$ NIDA42020 + $100 \mu \mathrm{g} / \mathrm{kg}$ capsazepine $+31 \mu \mathrm{g} / \mathrm{kg}$ cannabidiol (Fig. 5f).

\section{Discussion}

\section{General}

Palmitoylethanolamide has emerged as an interesting molecule with several potential therapeutic uses (e.g., in the treatment of neuropathic pain [32]). At the cardiovascular level, palmitoylethanolamide is known to boost the effects of classic endocannabinoids such as anandamide, but its potential direct role in the vascular system remains unclear [14]. Indeed, anandamide and analogues exert complex triphasic effects on blood pressure [33], which 


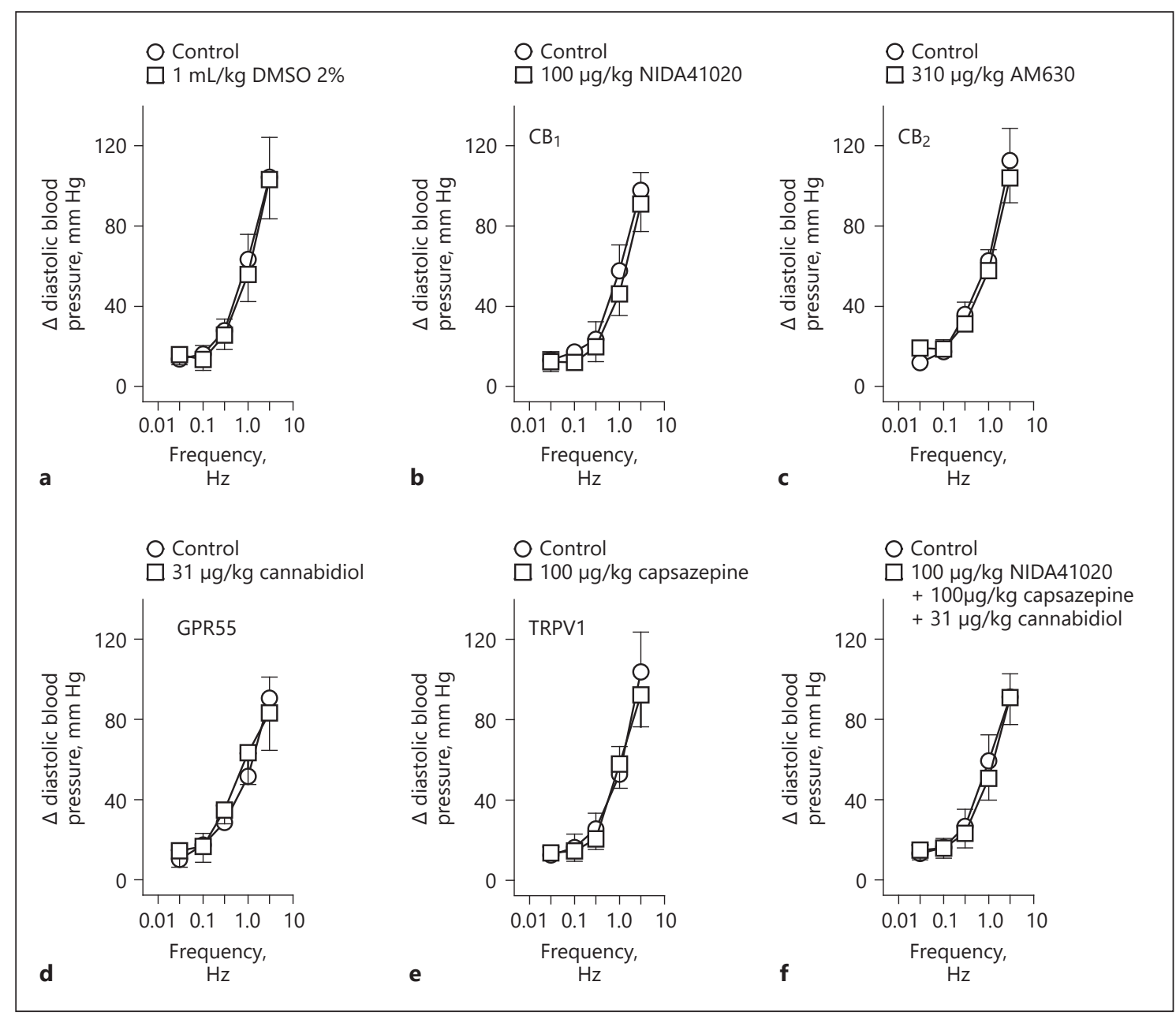

Fig. 3. Effect per se of i.v. bolus injections ( $n=5$ for each figure) of: $1 \mathrm{~mL} / \mathrm{kg}$ DMSO $2 \%$ (a); $100 \mu \mathrm{g} / \mathrm{kg}$ NIDA41020 (b); $310 \mu \mathrm{g} / \mathrm{kg}$ AM630 (c); $100 \mu \mathrm{g} / \mathrm{kg}$ capsazepine (d); $31 \mu \mathrm{g} / \mathrm{kg}$ cannabidiol (e), and the combination $100 \mu \mathrm{g} / \mathrm{kg}$ NIDA41020 $+100 \mu \mathrm{g} / \mathrm{kg}$ capsazepine $+31 \mu \mathrm{g} / \mathrm{kg}$ cannabidiol (f) on the electrically induced vasopressor responses. Empty symbols depict either control responses $(O)$ or non-significant $(p>0.05)$ responses $(\square)$ versus the control. Note that no compound produced significant effects $(p>0.05$ in all comparisons).

basically consist of: (i) a quick transitory decrease in diastolic blood pressure; (ii) a rapid increase in diastolic blood pressure; and (iii) a long-lasting hypotension. Accordingly, this study has made an attempt to identify the pharmacological profile of the palmitoylethanolamide sensitive-receptors mediating inhibition of the vasopressor responses induced by sympathetic stimulation or exogenous noradrenaline. Apart from the implications discussed below and recognising the complex pharmacological properties of the majority of the compounds used (Table 1), the present study shows that, in addition to the hypotension induced by palmitoylethanolamide, this compound inhibits the vasopressor responses induced by electrical sympathetic stimulation and exogenous noradrenaline. In all cases, the receptors involved resemble the pharmacological profile of $\mathrm{CB}_{1}, \mathrm{TRPV}_{1}$ and GPR55 receptors, but not of $\mathrm{CB}_{2}$ receptors. Together, these findings shed further light on the potential role of palmitoylethanolamide for modulating per se the systemic vascular tone (i.e., the vasopressor responses to sympathetic stimulation and exogenous noradrenaline) and not only as an "entourage" compound.

It is important to note that all antagonists (used at doses high enough to completely block their respective receptors in pithed rats $[8,9])$ failed to modify per se the baseline diastolic blood pressure and heart rate. There- 


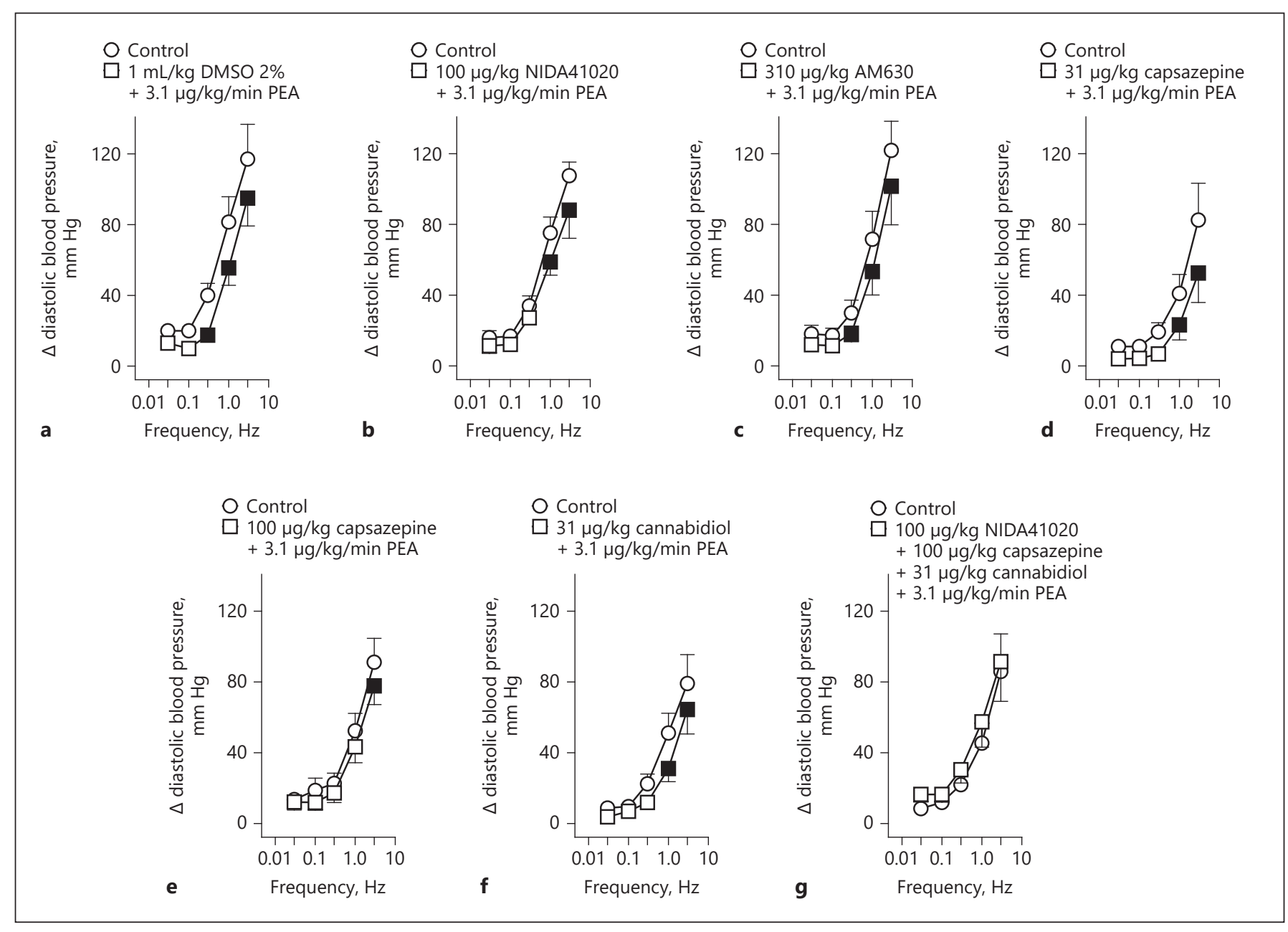

Fig. 4. Effect of i.v. bolus injections of: DMSO 2\% ( $1 \mathrm{~mL} / \mathrm{kg}$ each; a); $100 \mu \mathrm{g} / \mathrm{kg}$ NIDA41020 (b); $310 \mu \mathrm{g} / \mathrm{kg}$ AM630 (c); 31 and $100 \mu \mathrm{g} / \mathrm{kg}$ capsazepine (d, e); $31 \mu \mathrm{g} / \mathrm{kg}$ cannabidiol (f), and the combination $100 \mu \mathrm{g} / \mathrm{kg}$ NIDA41020 $+100 \mu \mathrm{g} / \mathrm{kg}$ capsazepine $+31 \mu \mathrm{g} / \mathrm{kg}$ cannabidiol (g) on palmitoylethanolamide (PEA)-induced inhibition of the vasopressor responses induced by electrical stimulation of the preganglionic $\left(\mathrm{T}_{7}-\mathrm{T}_{9}\right)$ sympathetic outflow in pithed rats. Empty symbols depict either control responses $(O)$ or non-significant $(p>0.05)$ responses $(\square)$ versus the control. Solid symbols $(\boldsymbol{\square})$ represent significantly different responses $(p<0.05)$ versus the control.

fore, any effect of a given antagonist on the vasopressor sympathoinhibition can be attributed to a direct interaction of the antagonist with its respective receptors on the vasopressor sympathetic nerves and not to physiological antagonism.

\section{Changes on Systemic Haemodynamic Variables \\ Produced by the Different Treatments}

A remarkable finding of our study was the capability of 1 and $3.1 \mu \mathrm{g} / \mathrm{kg} / \mathrm{min}$ palmitoylethanolamide to produce hypotension in pithed rats (which typically have a low baseline diastolic blood pressure as the central nervous system is not operative; Table 2), and that this re- sponse was blocked by pretreatment with NIDA41020, capsazepine or cannabidiol, but not by AM630 (Table 3). The simplest interpretation of these findings would be that palmitoylethanolamide-induced hypotension involves the activation of $\mathrm{CB}_{1}$, TRPV1 and GPR55, but not $\mathrm{CB}_{2}$, receptors. Nevertheless, palmitoylethanolamide is capable of inducing vasorelaxation by the activation of receptor-dependent and independent mechanisms on vascular smooth muscle $[14,31]$.

Admittedly, one limitation of the present study is that our results do not allow us to discriminate between direct versus indirect actions induced by palmitoylethanolamide. In this respect, one possibility that this study did 


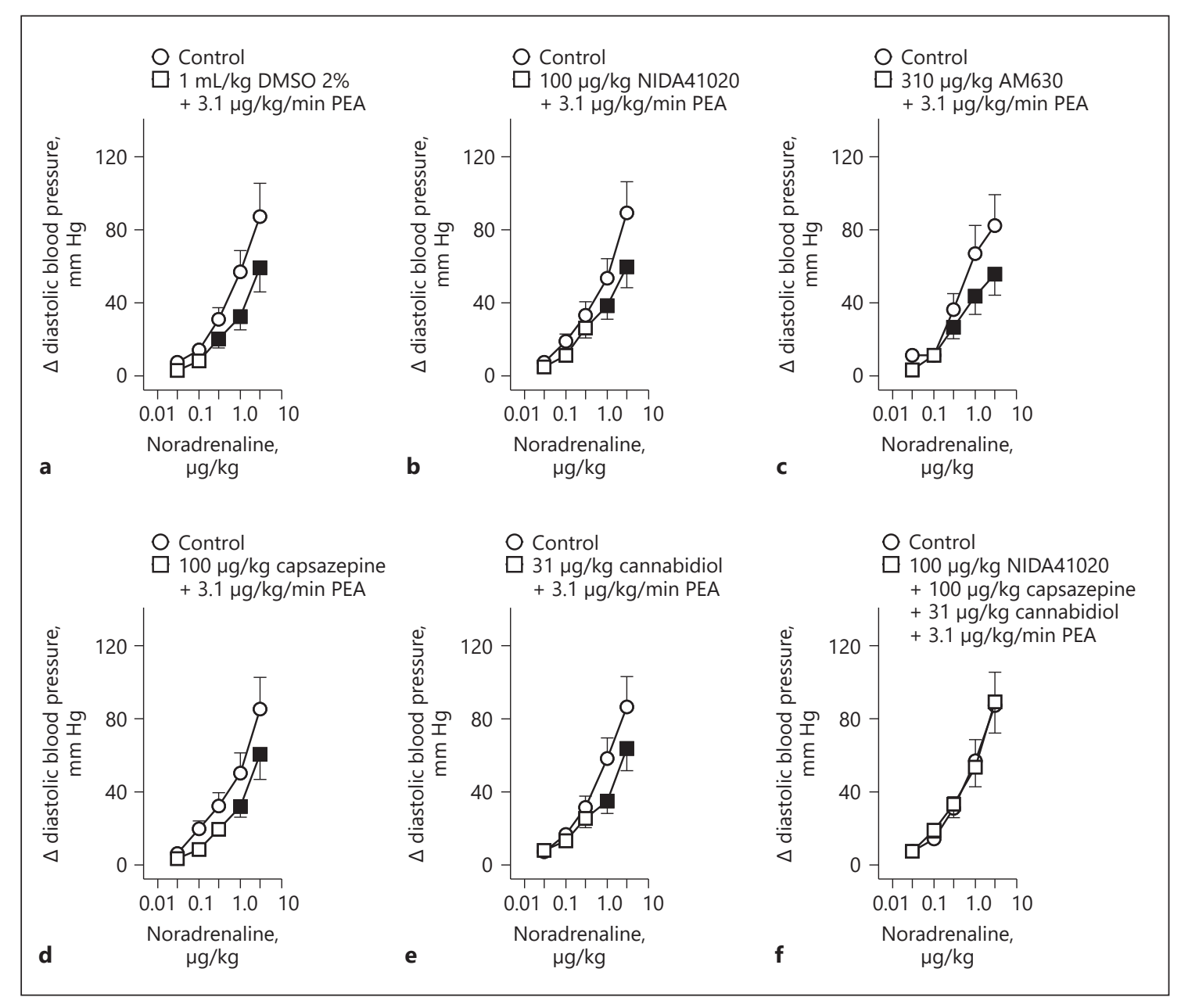

Fig. 5. Effect of i.v. bolus injections of: DMSO 2\% ( $1 \mathrm{~mL} / \mathrm{kg}$ each; a); $100 \mu \mathrm{g} / \mathrm{kg}$ NIDA41020 (b); $310 \mu \mathrm{g} / \mathrm{kg}$ AM630 (c); $100 \mu \mathrm{g} / \mathrm{kg}$ capsazepine (d); $31 \mu \mathrm{g} / \mathrm{kg}$ cannabidiol (e), and the combination $100 \mu \mathrm{g} / \mathrm{kg}$ NIDA41020 + $100 \mu \mathrm{g} /$ $\mathrm{kg}$ capsazepine $+31 \mu \mathrm{g} / \mathrm{kg}$ cannabidiol (f) on palmitoylethanolamide (PEA)-induced inhibition of the vasopressor responses induced by noradrenaline in pithed rats. Empty symbols depict either control responses (O) or non-significant $(p>0.05)$ responses $(\square)$ versus the control. Solid symbols $(\boldsymbol{\square})$ represent significantly different responses $(p<0.05)$ versus the control.

not explore is the potential interference of palmitoylethanolamide with the RAAS, in view that in pithed rats a proportion of blood pressure seems to be maintained by activation of the RAAS, as reported by Schlicker et al. [30]. Consistent with this possibility, infusions of angiotensin II produce tachycardic and vasopressor responses $[33,34]$. Clearly, this is a hypothetical speculation that requires other experimental approaches that include the use of i.v. bolus injections of palmitoylethanolamide in pithed rats whose low resting blood pressure is restored by an i.v. continuous infusion of a vasoconstrictor agent (with the RAAS pharmacological approach implemented by Schlicker et al. [30]).

Vasodepressor Actions of

Palmitoylethanolamide

\section{Possible Mechanisms Involved in the Inhibition by} Palmitoylethanolamide of the Vasopressor Responses Induced by Sympathetic Stimulation or Exogenous Noradrenaline

Our results show that the vasopressor responses induced by electrical sympathetic stimulation and exogenous noradrenaline were dose-dependently inhibited by palmitoylethanolamide. These inhibitory responses cannot be attributed to tachyphylaxis as the control responses remained unchanged after vehicle (Fig. 1a, 2a). An additional fact drawn from this finding is that no time-dependent changes occurred in our experiments. Moreover, it is worth emphasising that we did not measure electri- 
cally induced perivascular sympathetic nerve activity directly, but the electrically induced neurotransmitter release in the systemic vasculature could be estimated indirectly by measurement of the evoked vasopressor response. In this respect, it may be noted that there was some degree of variability in the control vasopressor responses of the different (sub)groups (Fig. 1-5), as similarly observed in other studies [25, 22, 26, 27]. This is most likely due to individual differences in each animal, but this biological variability certainly has no bearing on the results obtained with the different compounds, as each effect was analysed within the same group of animals, as previously reported [22, 25-27].

The inhibition of the vasopressor responses by sympathetic stimulation seems to be predominantly mediated by TRPV1 receptors, as capsazepine induced a more pronounced blockade of these responses (Fig. 4e) as compared to that produced for the vasopressor responses to exogenous noradrenaline (Fig. $5 \mathrm{~d}$ ). These results suggest that TRPV1 receptors may be mainly located prejunctionally (i.e., on perivascular sympathetic neurons). As TRPV1 receptors are cationic channels related with the excitation and transmission of action potentials, its activity on sympathetic nerves would result in noradrenaline release rather than inhibition. Interestingly, activation of prejunctional TRPV1 receptors on sensory CGRPergic perivascular fibres is classically associated with CGRP release and vasodilatation [35]. Moreover, it has been reported that palmitoylethanolamide activates TRPV1 channels [36]; on the other hand, part of its entourage effect is mediated via TRPV1 [14]. Thus, one possibility for explaining the inhibition by palmitoylethanolamide sensitive to capsazepine is by its possible inhibition of CGRP release from perivascular sensory CGRPergic nerves. Clearly, this speculation needs to be further investigated with additional experiments that fall beyond the scope of the present study.

It is important to highlight that NIDA141020 (a CB receptor antagonist) and cannabidiol (a GPR55 antagonist with other complex pharmacological properties) induced a slight blockade of the inhibition by palmitoylethanolamide on the sympathetic vasopressor responses (Fig. 4b, f, respectively). This blockade suggests the involvement of $\mathrm{CB}_{1}$ and GPR55 receptors, respectively. Indeed, $\mathrm{CB}_{1}$ receptors have been associated with the inhibition of noradrenaline release in the systemic vasculature of pithed rats [8]. However, as the affinity of palmitoylethanolamide for $\mathrm{CB}_{1}$ receptors is rather low (Table 1), it is possible that this effect is also induced by the entourage effect classically described for palmitoylethanolamide rather than a direct interaction [37]. Finally, the partial blockade by cannabidiol (GPR55 antagonist; Table 1) of the inhibition induced by palmitoylethanolamide on the vasopressor responses is probably mediated by endothelial GPR55 receptors, which have been reported to induce vasodilatation $[8,10]$.

In the case of the vasopressor responses induced by exogenousnoradrenaline, the antagonists NIDA16020046 $\left(\mathrm{CB}_{1}\right)$, capsazepine (TRPV1), and cannabidiol (GPR55), but not AM630 $\left(\mathrm{CB}_{2}\right)$, induced a partial blockade of the inhibition induced by palmitoylethanolamide when given separately. These results suggest that the inhibition of noradrenaline-induced vasopressor responses involves the sum of a combination of effects mediated by $\mathrm{CB}_{1}$, TRPV1, and GPR55 receptors. This idea is further supported by the fact that only the combination of $\mathrm{CB}_{1}$, TRPV1 and GPR55 antagonists could abolish this vasopressor response (Fig. 5f). The same pharmacological profile was observed in the sympathetic vasopressor responses (Fig. 4g). Similar results have been reported where palmitoylethanolamide induces its effects via a complex interaction with $\mathrm{CB}_{1}, \mathrm{CB}_{2}$, TRPV1, GPR55 and PPAR receptors and channels [38].

\section{Potential Clinical Implications for the Use of \\ Palmitoylethanolamide}

Palmitoylethanolamide is commercially available and has recently been suggested for therapeutic use as an antiinflammatory agent and against retinopathy [39]. Its chronic use has also been suggested to increase the quality of life in patients with certain types of pain [40] and to decrease pain symptoms in patients with fibromyalgia [41]. Nevertheless, these studies seem to be devoid of a careful analysis on the potential side effects, particularly the cardiovascular consequences of the use of palmitoylethanolamide. Our results in pithed rats, an experimental model predictive of systemic cardiovascular side effects [42] that cannot be obtained from in vitro studies [43], suggest that palmitoylethanolamide produces hypotension and an attenuation of the sympathetic vasopressor outflow. These potential vascular side effects should be considered in future clinical studies analysing the therapeutic uses of palmitoylethanolamide.

\section{Conclusion}

Taken together, our results suggest that palmitoylethanolamide induced hypotension and an inhibition of the noradrenergic vasopressor responses via complex inter-
Marichal-Cancino et al. 
actions that involve $\mathrm{CB}_{1}$ (sympathetic), TRPV1 (sensory) and GPR55 (endothelial) receptors. Hence, it seems very likely that the functional activation of these prejunctional and endothelial receptors by palmitoylethanolamide would explain, at least in part, the hypotension produced by this compound.

\section{Acknowledgements}

The authors would like to thank Mr. Mauricio Villasana and Engr. José Rodolfo Fernández-Calderón for their assistance.

\section{Statement of Ethics}

All experimental protocols in this study were approved by our Institutional Ethics Committee (CICUAL-Cinvestav; permission protocol No. 507-12) in accordance with the guide for the Care and Use of Laboratory Animals in the USA [44] and with the ARRIVE guidelines [45].

\section{Disclosure Statement}

All authors declare that they have no competing interests.

\section{Funding Sources}

Prof. Carlos M. Villalón was financially supported by the SEPCinvestav Research Support Fund (grant No. 50). Dr. Bruno A. Marichal Cancino was financially supported by "Dirección General de Investigación y Posgrado" from Autonomous University of Aguascalientes (grant PIBB19-1).

\section{Author Contributions}

B.A.M.-C. performed the experiments and participated in the design of the study with C.M.V.; E.R.-S.J. and B.A.M.-C. performed the data analysis and produced the graphs. A.M., A.G.-H., C.M.V., and B.A.M.-C. participated in the data interpretation and writing of the manuscript. All authors read and approved the final manuscript.

\section{References}

1 Marichal-Cancino BA, Sánchez-Fuentes A, Méndez-Díaz M, Ruiz-Contreras AE, Prospéro-García O. Blockade of GPR55 in the dorsolateral striatum impairs performance of rats in a T-maze paradigm. Behav Pharmacol. 2016 Jun;27(4):393-6.

2 Sánchez-Fuentes A, Marichal-Cancino BA, Méndez-Díaz M, Becerril-Meléndez AL, Ruiz-Contreras AE, Prospéro-Garcia O. mGluR1/5 activation in the lateral hypothalamus increases food intake via the endocannabinoid system. Neurosci Lett. 2016 Sep;631: 104-8.

3 Marichal-Cancino BA, Fajardo-Valdez A, Ruiz-Contreras AE, Mendez-Díaz M, Prospero-García O. Advances in the Physiology of GPR55 in the Central Nervous System. Curr Neuropharmacol. 2017;15(5):771-8.

4 Rosenberg EC, Patra PH, Whalley BJ. Therapeutic effects of cannabinoids in animal models of seizures, epilepsy, epileptogenesis, and epilepsy-related neuroprotection. Epilepsy Behav. 2017 May;70(Pt B):319-27. https:// doi.org/10.1016/j.yebeh.2016.11.006.

5 Guerrero-Alba R, Barragán-Iglesias P, González-Hernández A, Valdez-Moráles EE, Granados-Soto V, Condés-Lara $\mathrm{M}$, et al. Some prospective alternatives for treating pain: the endocannabinoid system and its putative receptors GPR18 and GPR55. Front Pharmacol. 2019 Jan;9:1496.

6 Marichal-Cancino BA, Fajardo-Valdez A, Ruiz-Contreras AE, Méndez-Díaz M, Prospéro-García O. Possible role of hippocampal GPR55 in spatial learning and memory in rats. Acta Neurobiol Exp (Warsz). 2018;78(1): 41-50.
7 Ramírez-Orozco RE, García-Ruiz R, Morales P, Villalón CM, Villafán-Bernal JR, MarichalCancino BA. Potential metabolic and behavioural roles of the putative endocannabinoid receptors GPR18, GPR55 and GPR119 in feeding. Curr Neuropharmacol. 2019;17(10): 947-60.

8 Marichal-Cancino BA, Manrique-Maldonado G, Altamirano-Espinoza AH, Ruiz-Salinas I, González-Hernández A, Maassenvandenbrink A, et al. Analysis of anandamide- and lysophosphatidylinositol-induced inhibition of the vasopressor responses produced by sympathetic stimulation or noradrenaline in pithed rats. Eur J Pharmacol. 2013 Dec;721(13):168-77.

9 Marichal-Cancino BA, Altamirano-Espinoza AH, Manrique-Maldonado G, MaassenVanDenBrink A, Villalón CM. Role of pre-junctional CB1, but not CB2, TRPV1 or GPR55 receptors in anandamide-induced inhibition of the vasodepressor sensory CGRPergic outflow in pithed rats. Basic Clin Pharmacol Toxicol. 2014 Mar;114(3):240-7.

10 AlSuleimani YM, Hiley CR. The GPR55 agonist lysophosphatidylinositol relaxes rat mesenteric resistance artery and induces $\mathrm{Ca}(2+)$ release in rat mesenteric artery endothelial cells. Br J Pharmacol. 2015 Jun;172(12):304357.

11 Malinowska B, Baranowska-Kuczko M, Schlicker E. Triphasic blood pressure responses to cannabinoids: do we understand the mechanism? Br J Pharmacol. 2012 Apr; 165(7):2073-88.

12 O'Sullivan SE, Kendall DA, Randall MD Time-dependent vascular effects of endocan- nabinoids mediated by peroxisome proliferator-activated receptor gamma (PPAR $\gamma$ ). PPAR Res. 2009;2009:425289.

13 Zakrzeska A, Schlicker E, Baranowska M, Kozłowska H, Kwolek G, Malinowska B. A cannabinoid receptor, sensitive to O-1918, is involved in the delayed hypotension induced by anandamide in anaesthetized rats. $\mathrm{Br} \mathrm{J}$ Pharmacol. 2010 Jun;160(3):574-84.

14 Ho WS, Barrett DA, Randall MD. 'Entourage' effects of N-palmitoylethanolamide and $\mathrm{N}$ oleoylethanolamide on vasorelaxation to anandamide occur through TRPV1 receptors. Br J Pharmacol. 2008 Nov;155(6):837-46.

15 Richardson D, Ortori CA, Chapman V, Kendall DA, Barrett DA. Quantitative profiling of endocannabinoids and related compounds in rat brain using liquid chromatography-tandem electrospray ionization mass spectrometry. Anal Biochem. 2007 Jan;360(2):216-26.

16 Balvers MG, Verhoeckx KC, Meijerink J, Wortelboer HM, Witkamp RF. Measurement of palmitoylethanolamide and other $\mathrm{N}$-acylethanolamines during physiological and pathological conditions. CNS Neurol Disord Drug Targets. 2013 Feb;12(1):23-33.

17 Petrosino S, Schiano Moriello A, Cerrato S, Fusco M, Puigdemont A, De Petrocellis L, et al. The anti-inflammatory mediator palmitoylethanolamide enhances the levels of 2-arachidonoyl-glycerol and potentiates its actions at TRPV1 cation channels. Br J Pharmacol. 2016 Apr;173(7):1154-62.

18 Godlewski G, Offertáler L, Wagner JA, Kunos G. Receptors for acylethanolamides-GPR55 and GPR119. Prostaglandins Other Lipid Mediat. 2009 Sep;89(3-4):105-11. 
19 Chaudhry RR. Physiology, cardiovascular. In: StatPearls. Treasure Island: StatPearls; 2019. Available from: https://www.ncbi.nlm.nih. gov/books/NBK493197/

20 de Simone G, Pasanisi F. Systolic, diastolic and pulse pressure: pathophysiology. Ital Heart J Suppl. 2001 Apr;2(4):359-62. Italian.

21 Shipley RE, Tilden JH. A pithed rat preparation suitable for assaying pressor substances. Proceedings of the Society for Experimental Biology and Medicine Society for Experimental Biology and Medicine (New York, NY). 1947 Apr;64(4):453-5.

22 Villalón CM, Centurión D, Rabelo G, de Vries P, Saxena PR, Sánchez-López A. The 5-HT1like receptors mediating inhibition of sympathetic vasopressor outflow in the pithed rat: operational correlation with the 5-HT1A, 5-HT1B and 5-HT1D subtypes. Br J Pharmacol. 1998 Jul;124(5):1001-11.

23 Kleinman LI, Radford EP Jr. Ventilation standards for small mammals. J Appl Physiol. 1964 Mar;19(2):360-2.

24 Gillespie JS, Maclaren A, Pollock D. A method of stimulating different segments of the autonomic outflow from the spinal column to various organs in the pithed cat and rat. $\mathrm{Br} \mathrm{J}$ Pharmacol. 1970 Oct;40(2):257-67.

25 Villalón CM, Contreras J, Ramŕiez-San Juan E, Castillo C, Perusquía M, López-Muñoz FJ, et al. 5-hydroxytryptamine inhibits pressor responses to preganglionic sympathetic nerve stimulation in pithed rats. Life Sci. 1995; 57(8):803-12.

26 Ruiz-Salinas I, González-Hernández A, Manrique-Maldonado G, Marichal-Cancino BA, Altamirano-Espinoza AH, Villalón CM. Predominant role of the dopamine D3 receptor subtype for mediating the quinpirole-induced inhibition of the vasopressor sympathetic outflow in pithed rats. Naunyn Schmiedebergs Arch Pharmacol. 2013 May;386(5): 393-403.

27 Ruiz-Salinas I, Rocha L, Marichal-Cancino BA, Villalón CM. Cardiovascular Alterations during the Interictal Period in Awake and Pithed Amygdala-Kindled Rats. Basic Clin Pharmacol Toxicol. 2016 Aug;119(2):165-72.

28 Curtis MJ, Bond RA, Spina D, Ahluwalia A, Alexander SP, Giembycz MA, et al. Experimental design and analysis and their reporting: new guidance for publication in BJP. Br J Pharmacol. 2015 Jul;172(14):3461-71.

29 Steel RG. Principles and procedures of statistics, a biomedical approach.2nd ed. Tokyo: Kogakushao; 1980.

30 Schlicker E, Erkens K, Göthert M. Probable involvement of vascular angiotensin II formation in the beta 2 -adrenoceptor-mediated facilitation of the neurogenic vasopressor re- sponse in the pithed rat. Naunyn Schmiedebergs Arch Pharmacol. 1988 Nov;338(5): $536-42$.

31 White R, Hiley CR. The actions of some cannabinoid receptor ligands in the rat isolated mesenteric artery. Br J Pharmacol. 1998 Oct; 125(3):533-41.

32 Hesselink JM, Hekker TA. Therapeutic utility of palmitoylethanolamide in the treatment of neuropathic pain associated with various pathological conditions: a case series. J Pain Res. 2012;5:437-42.

33 Knape JTA, van Zwieten PA. Positive chronotropic activity of angiotensin II in the pithed normotensive rat is primarily due to activation of cardiac $\beta 1$-adrenoceptors. NaunynSchmiedebergs Arch Pharmacol. 1988;338(2): 185-90. https://doi.org/10.1007/BF00174868.

34 Zhang J, Pfaffendorf M, van Zwieten PA. Positive inotropic action of angiotensin II in the pithed rat. Naunyn Schmiedebergs Arch Pharmacol. 1993 Jun;347(6):658-63.

35 Marichal-Cancino BA, González-Hernández A, Manrique-Maldonado G, Ruiz-Salinas II, Altamirano-Espinoza AH, MaassenVanDenBrink A, et al. Intrathecal dihydroergotamine inhibits capsaicin-induced vasodilatation in the canine external carotid circulation via GR127935- and rauwolscine-sensitive receptors. Eur J Pharmacol. 2012 Oct;692(1-3):6977.

36 Ambrosino P, Soldovieri MV, Russo C, Taglialatela M. Activation and desensitization of TRPV1 channels in sensory neurons by the PPARa agonist palmitoylethanolamide. $\mathrm{Br} \mathrm{J}$ Pharmacol. 2013 Mar;168(6):1430-44.

37 García MC, Adler-Graschinsky E, Celuch SM. Enhancement of the hypotensive effects of intrathecally injected endocannabinoids by the entourage compound palmitoylethanolamide. Eur J Pharmacol. 2009 May;610(1-3): 75-80.

38 Borrelli F, Romano B, Petrosino S, Pagano E, Capasso R, Coppola D, et al. Palmitoylethanolamide, a naturally occurring lipid, is an orally effective intestinal anti-inflammatory agent. Br J Pharmacol. 2015 Jan;172(1):14258.

39 Keppel Hesselink JM, Costagliola C, Fakhry J, Kopsky DJ. Palmitoylethanolamide, a natural retinoprotectant: its putative relevance for the treatment of glaucoma and diabetic retinopathy. J Ophthalmol. 2015;2015:430596.

40 Caruso S, Iraci Sareri M, Casella E, Ventura B, Fava V, Cianci A. Chronic pelvic pain, quality of life and sexual health of women treated with palmitoylethanolamide and $\alpha$-lipoic acid. Minerva Ginecol. 2015 Oct;67(5):413-9.

41 Del Giorno R, Skaper S, Paladini A, Varrassi G, Coaccioli S. Palmitoylethanolamide in Fi- bromyalgia: Results from Prospective and Retrospective Observational Studies. Pain Ther. 2015 Dec;4(2):169-78.

42 Valdivia LF, Centurión D, Perusquía M, Arulmani U, Saxena PR, Villalón CM. Pharmacological analysis of the mechanisms involved in the tachycardic and vasopressor responses to the antimigraine agent, isometheptene, in pithed rats. Life Sci. 2004 May;74(26):322334.

43 Gupta S, Villalón CM. The relevance of preclinical research models for the development of antimigraine drugs: focus on 5-HT(1B/1D) and CGRP receptors. Pharmacol Ther. 2010 Oct;128(1):170-90

44 Bayne K. Revised guide for the care and use of laboratory animals. American Physiological Society. Physiologist. 1996 Aug;39(4):208-11.

45 McGrath JC, Drummond GB, McLachlan EM, Kilkenny C, Wainwright CL. Guidelines for reporting experiments involving animals: the ARRIVE guidelines. Br J Pharmacol. 2010 Aug;160(7):1573-6.

46 Ryberg E, Larsson N, Sjögren S, Hjorth S, Hermansson NO, Leonova J, et al. The orphan receptor GPR55 is a novel cannabinoid receptor. Br J Pharmacol. 2007 Dec;152(7): 1092-101.

47 Katoch-Rouse R, Pavlova OA, Caulder T, Hoffman AF, Mukhin AG, Horti AG. Synthesis, structure-activity relationship, and evaluation of SR141716 analogues: development of central cannabinoid receptor ligands with lower lipophilicity. J Med Chem. 2003 Feb; 46(4):642-5.

48 Donohue SR, Halldin C, Pike VW. Synthesis and structure-activity relationships (SARs) of 1,5-diarylpyrazole cannabinoid type-1 $(\mathrm{CB}(1))$ receptor ligands for potential use in molecular imaging. Bioorg Med Chem. 2006 Jun;14(11):3712-20.

49 Ross RA, Brockie HC, Stevenson LA, Murphy VL, Templeton F, Makriyannis A, et al. Agonist-inverse agonist characterization at $\mathrm{CB} 1$ and CB2 cannabinoid receptors of L759633, L759656, and AM630. Br J Pharmacol. 1999 Feb;126(3):665-72.

50 Ross RA, Gibson TM, Brockie HC, Leslie M, Pashmi G, Craib SJ, et al. Structure-activity relationship for the endogenous cannabinoid, anandamide, and certain of its analogues at vanilloid receptors in transfected cells and vas deferens. Br J Pharmacol. 2001 Feb;132(3): 631-40.

51 Thomas A, Baillie GL, Phillips AM, Razdan RK, Ross RA, Pertwee RG. Cannabidiol displays unexpectedly high potency as an antagonist of CB1 and CB2 receptor agonists in vitro. Br J Pharmacol. 2007 Mar;150(5):61323. 